УAK 332.3

Niu Lichen,

Postgraduate student, Sumy National Agrarian University, Sumy

DOI: $10.32702 / 2306-6792.2019 .11 .65$

\title{
ORGANIZATIONAL AND ECONOMIC ASPECTS OF LAND USE IN AGRICULTURE OF CHINA
}

Ню аспірант, Сумський національний аграрний університет, Суми ORCID ID: 0000-0003-0481-846X

\author{
ОРГАНІЗАЦІЙНО-ЕКОНОМІЧНІ АСПЕКТИ ВИКОРИСТАННЯ ЗЕМЕАЬ В СІАЬСЬКОМУ \\ ГОСПОААРСТВІ КИТАЮ
}

Under the current economic background, the effective use of land can ensure the stable and healthy development of individual enterprises and national economy. The primary task of China today is to complete land reform, standardize and adjust land relations, and make investment more standardized and transparent in the field of agricultural development. Supply and demand can not be carried out in accordance with market principles, there are significant differences in farmers'income, these factors are affected by the land system.

Effective and rational use of agricultural land in China can greatly alleviate the situation of large population and small land in our country, make rational use of land and promote technological transformation and industrial upgrading of modern agriculture. In this case, the establishment of appropriate market mechanism can better protect the interests of various organizations and farmers. Establishing the market mechanism of land resources allocation is of great significance to the rational use of land resources, the development of agriculture and the increase of farmers'income.

The purpose of this paper is to study the characteristics of agricultural land in China, to provide theoretical and practical basis for the smooth development of market mechanism in rural land in China, and to put forward the feasibility, necessity and reality of market mechanism. This will help to optimize the current situation of the agricultural sector and provide prospects and directions for future development. Nowadays, there are some problems in the current situation of agricultural land use in China, which need to be further improved. Only a few separate provinces use market mechanism in land use. In order to overcome the imbalance between supply and demand of agricultural land, market factors should be introduced into land circulation. However, the market often has some shortcomings, and the government should play an economic and political role. The government's macro-control must play an appropriate supporting role, but it should not be too cumbersome. It should establish a reliable social protection system for the rural population and farmers.

У сучасних умовах господарювання ефективне використання земель виступає запорукою стабільного функціонування як окремого підприємства, так економіки держави. ОАним із пріоритетних завдань Китаю $є$ завершення земельної реформи, а також забезпечення комфортних і прозорих правил земельних відносин для залучення інвестицій в аграрний сектор. Зміни попиту та пропозицій, значна диференціація доходів господарюючих суб'єктів, відмінності цінової політики здійснюють вагомий вплив на вартість окремої земельної Аілянки.

Ефективне використання сільськогосподарських угідь в Китаї, осучаснення організаційно-правових форм землеволодіння та землекористування має сприяти технологічній трансформації аграрного виробництва. При цьому актуальності набуває розробка відповідного механізму забезпечення розподілу наявних земельних угідь в розрізі різних організаційно-правових форм господарюючих суб'єктів. Основою відповідного механізму можна визначити ринкові засади розподілу наявного земельного фонду. Запровадження такого процесу сприятиме розвитку сільського господарства та збільшенню доходів населення у сільській місцевості. 
Метою написання наукової статті є дослідження особливостей сільськогосподарського землекористування в Китаї за умови імплементації окремих складових ринкового механізму, що сприятиме оптимізації значень індикаторів, які характеризують стан та подальші перспективи розвитку аграрного сектору країни.

Сучасне становище трансформації сільськогосподарського землекористування в Китаї потребує подальшого

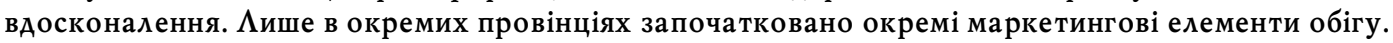

3 метою подолання дисбалансу між попитом і пропозицією наявних земельних угідь, сліА запровадити ринкові елементи регулювання цього виду ресурсів.

Враховуючи організаційно-політичні особливості функціонування економіки досліджуваної країни, сліА зазначити, що сільськогосподарське землекористування не може спиратися виключно на ринок. Макроекономічне регулювання і контроль уряду повинні відігравати відповідну допоміжну роль, але вона не може бути занадто обтяжливою. Органи державної влади мають створити надійну систему соціального захисту сільського населення, Арібних землекористувачів та фермерів.

Key word: competitive mechanism, macro-control, market mechanism, land transfer, supply and demand.

Ключові слова: конкурентний механізм, макроконтроль, ринковий механізм, передача землі, nопит та пропозищія.

\section{PROBLEM STATEMENT IN GENERAL FORM}

At present, after the land transfer in China, there are still many cultivated land unmanaged, which is caused by poor management and defrauding land transfer subsidies. Another factor affecting the formation of the land transfer market is the farmers' ideological understanding. Full-time farming can no longer guarantee the needs of farmers. Now many farmers subcontract the land to relatives and friends. Even a small number of full-time farmers have rarely cultivated new technologies, but traditional farming methods. Very rare. It can be seen that the role of marketoriented operations in land circulation has not yet been fully realized [2]. There is no effective competition in the process of land transfer, and the

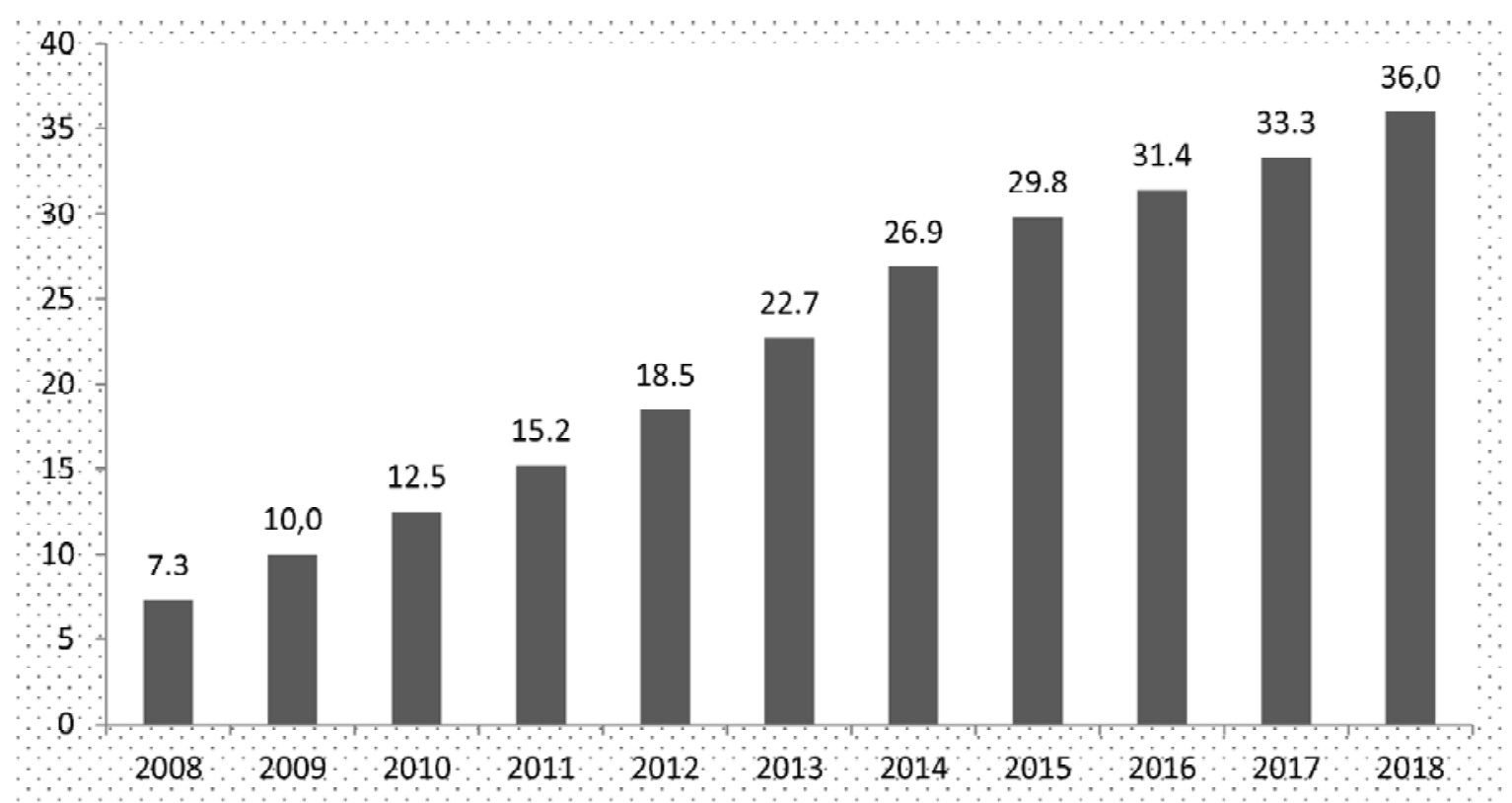

Fig. 1. China's land transfer area chart (unit: million hectares)

Data from: Ministry of Agriculture of China. 


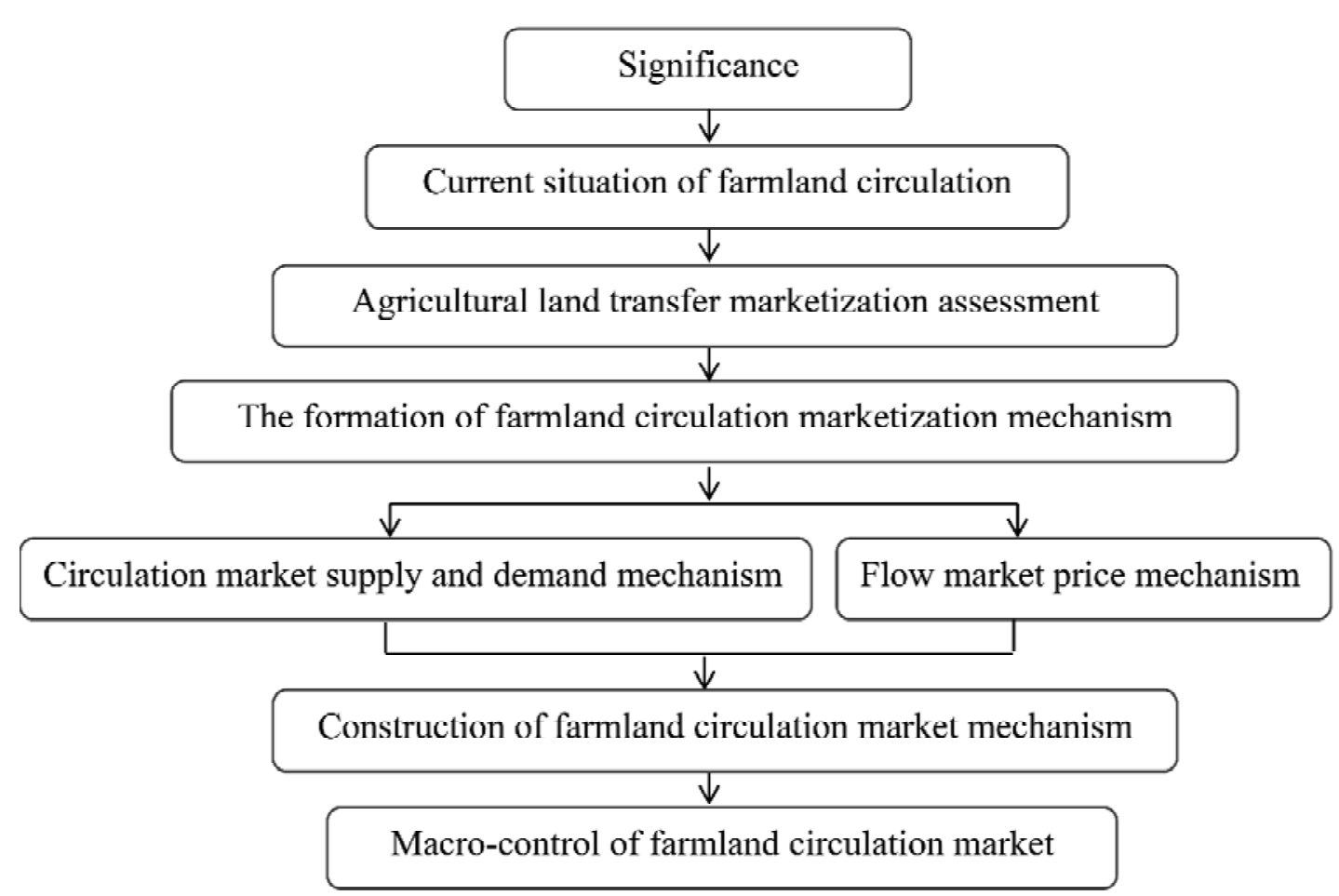

Fig. 2. Research ideas in this article

expected benefits of land transfer have not been realized. Starting from the actual situation in China, giving play to the basic role of market mechanism in land transfer is of great significance to China's land transfer.

\section{ANALYSIS OF RECENT RESEARCH AND PUBLICATIONS}

Chinese scholars have been conducting research on the transfer of agricultural land use rights. However, there are few studies on the market mechanism to control the transfer of agricultural land use rights. With the continuous innovation of the transfer of agricultural land use rights and the establishment of China's market economic system, the research on the market transfer of farmland use rights began to take off [1]. With the change of the land transfer mode, the transition from the period of helping farming and swapping has begun to lease and share various ways. This phenomenon has also begun to attract the attention of scholars. The land transfer between farmers has been paid, and the paid contracting of collective land has become the main content of the land market in recent years. The area of agricultural land transfer in China is on the rise (Fig. 1).

However, the impact of the market for agricultural land use rights on resource allocation is still inconclusive. Some scholars believe that the market mechanism is a way to effectively allocate land resources. Another group of scholars worry that under the influence of market mechanisms, there may be a concentration of land resources, leading to an increase in the gap between the rich and the poor in rural areas.

Domestic scholars Liu Xiangying, Jia Zhengwen, Guo Dong, Chen Yinrong. Mei Yun. and others believe that: "If there is no complete market system for land transfer, rural land will encounter many obstacles in the process of circulation. Many places lack a unified land transfer market. The service system has led to the failure of many rural land transfer to be effectively managed. Therefore, it is necessary to strengthen the construction of the land transfer market".

Sun Yujuan and Qiu Xiaoming pointed out: "The marketization of rural land transfer is to revitalize land resources, stimulate land vitality, and rationally allocate rural surplus labor. Integrate agricultural resources, further exert the effectiveness of land, and complete the commercial operation of land use rights. Land management rights will be transferred to the market through paid mechanisms, and land resources will be turned into capital, which will maximize the value of land and improve land utilization. The land that has been transferred will be centralized and integrated into a third-party operation. The operator will transform the traditional agriculture, marketoriented, adjust the industrial development structure according to market demand, implement scientific management methods, and invest in modern technology. Enter Improve land input and 


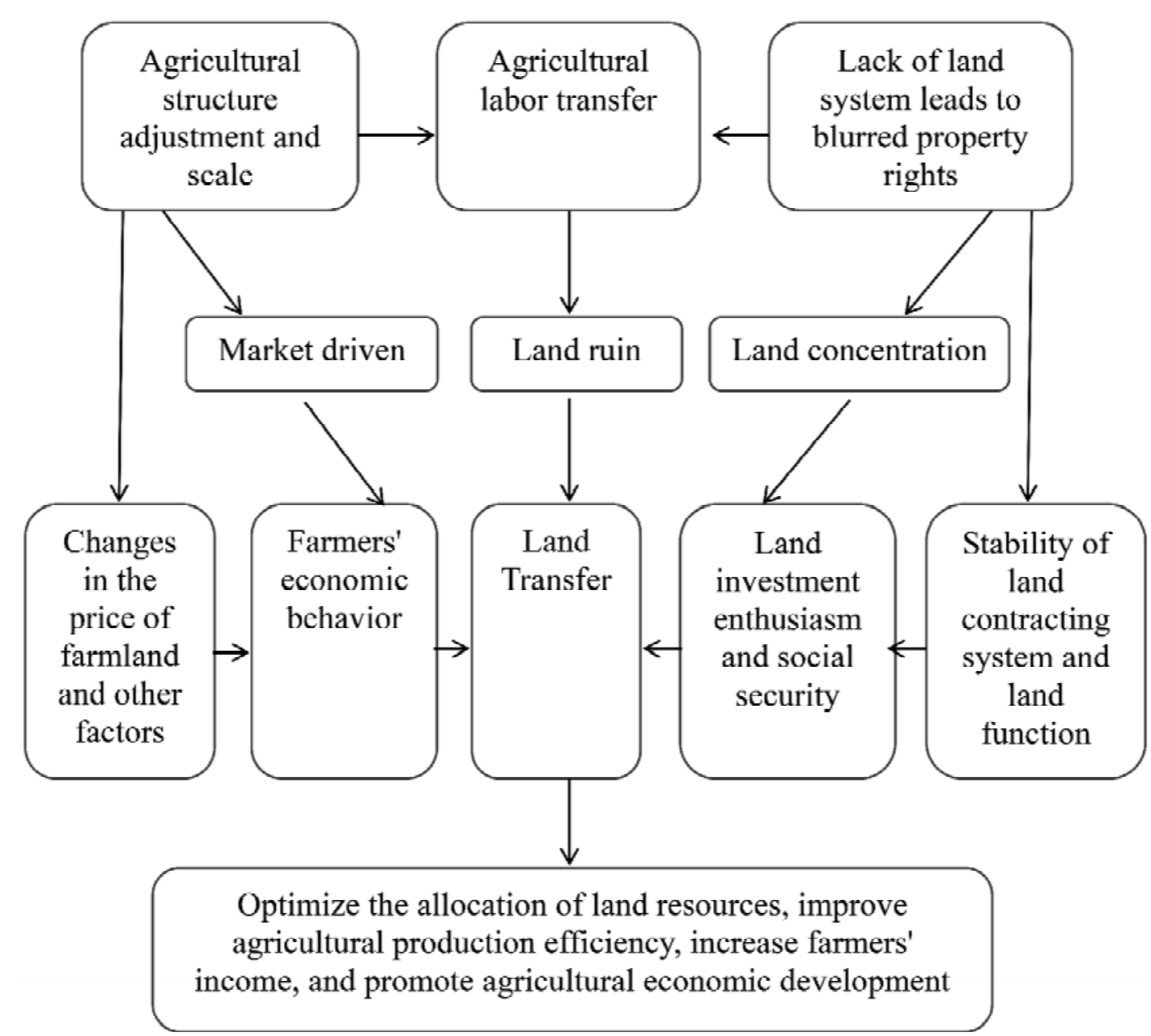

Fig. 3. The formation mechanism of rural land circulation

output efficiency, the development of large-scale operation, has important practical significance.

\section{IDENTIFY PREVIOUSLY UNRESOLVED PART OF THE PROBLEM}

In recent years, with the establishment and improvement of China's rural market economic system, there are more and more peasant land circulation phenomena, but the marketization direction is not obvious enough. Generally speaking, the land transfer is mostly between friends and relatives, and often does not charge any rent. Moreover, in the land transfer with market attributes, the scale of circulation is small, scattered, and the low efficiency of rural land resource allocation still exists. There are still many problems in the marketization of rural land circulation.

\section{THE PURPOSES FORMATION OF THE ARTICLE}

The purpose of this paper is to study the characteristics of agricultural land in China, to provide theoretical and practical basis for the smooth development of market mechanism in rural land in China, and to put forward the feasibility, necessity and reality of market mechanism (Fig. 2).

\section{PRESENTING THE MAIN MATERIAL}

The market-oriented assessment of land transfer, China's rural land transfer marketization assessment is the use of market mechanisms to judge the current marketization of land transfer in China. Strive to build a system for the formation of rural land transfer in China (Fig. 3).In order to maximize the benefits of their own land, farmers have to transfer their own land contractual management rights, which is one of the internal driving forces for the realization of marketoriented circulation. Therefore, to judge the degree of marketization of circulation, we must first look at whether the circulation price is marketized, free circulation, and the deviation of the circulation price from the market price is not market-oriented circulation. Secondly, to trade, it is necessary to consider whether the situation meets the legal requirements [3]. For example, it 


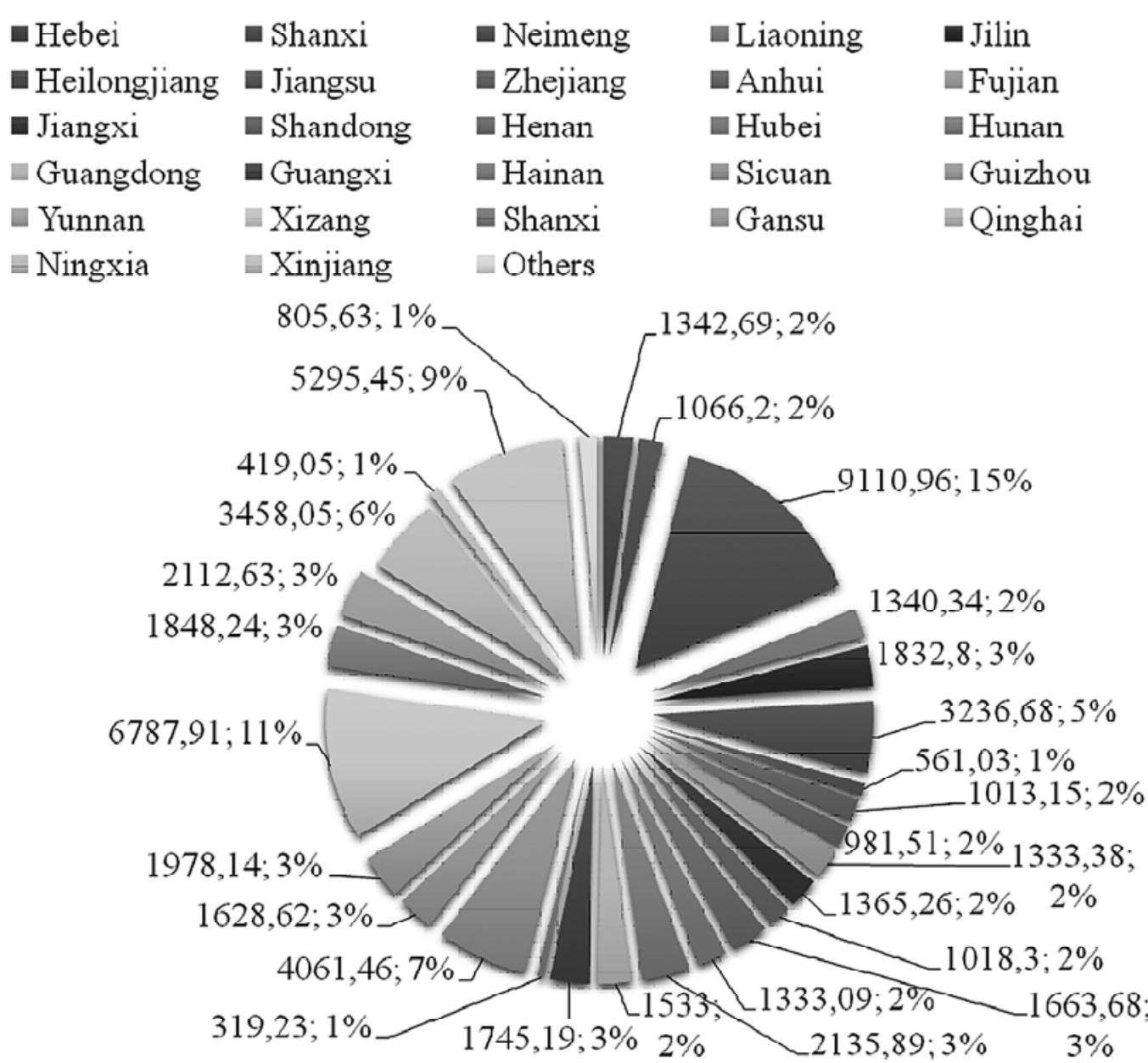

Fig. 4. Land area of various provinces in China (Unit: 10,000 hectares)

Data from: www. Baidu.com

is illegal to engage in real estate development by exploiting agriculture because he has changed the land use. Third, it depends on whether administrative power or monopolistic behavior interferes with the competition mechanism, so that competition cannot be carried out or the process of circulation does not compete at all. Finally, it depends on the increase in the efficiency of the land-based output after the land transfer.

The degree of marketization of agricultural land contracting management rights in China is very different: first, the form of circulation with a low degree of marketization, and the widespread free transfer in rural areas belong to this type. Second, there is a trend of marketoriented circulation, but it is not a real market- oriented circulation. For example, the mutual exchange of land reflects the market mechanism to a certain extent. All parties involved maintain their own interests with reference to market conditions, but the price formation The mechanism is still not obvious. Third, the form of land transfer with relatively high degree of marketization, such as the lease system and the shareholding system, the purpose of transferring the land contractual management right is to pursue the interests. Under this circumstance, the role of the market mechanism in the process of land transfer can be fully exerted. Class is the ideal market-based land transfer. However, in general, the shortcomings of small land circulation and low allocation efficiency of rural land resources

Table 1. Comparison of land transfer payments in 2015 and 2018 years

\begin{tabular}{|l|l|l|}
\hline \multicolumn{1}{|c|}{$\begin{array}{l}\text { Type of } \\
\text { operations }\end{array}$} & \multicolumn{1}{c|}{ 2015 year } & \multicolumn{1}{c|}{ 2018 year } \\
\cline { 2 - 3 } $\begin{array}{l}\text { Paid } \\
\text { transfer }\end{array}$ & Collect 5267 samples & Collect 4532 samples \\
\hline $\begin{array}{l}\text { Free } \\
\text { transfer }\end{array}$ & $2237(42.5 \%)$ & $3014(66.5 \%)$ \\
\hline
\end{tabular}

Data from: Financial investigation. 


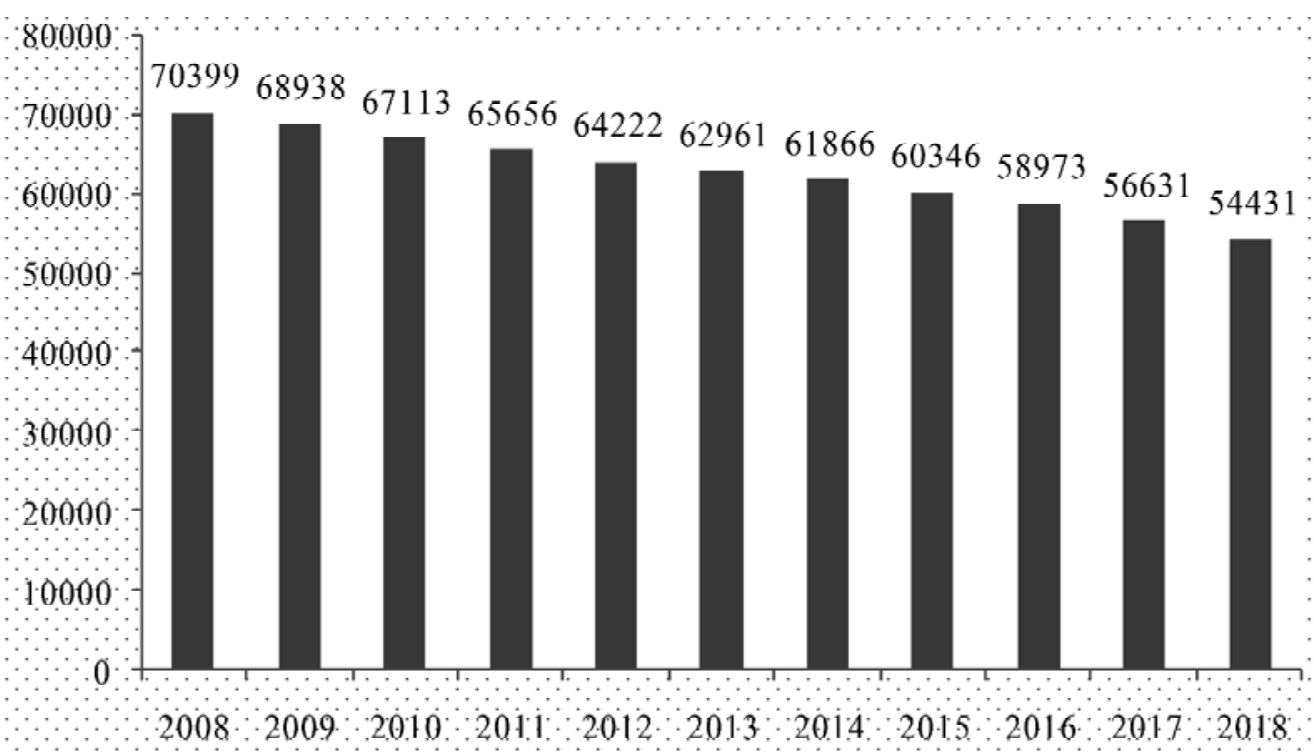

Fig. 5. Rural population chart (unit: 10,000 people)

Data from: Ministry of Agriculture of China.

still exist, and the first two methods are adopted in most parts of the country.

The necessity of the formation of rural land transfer market, Although China's agricultural land resources are relatively abundant, the agricultural land resources in each province are unevenly distributed (Figure 4). Due to the large population, China's per capita cultivated land area is ranked 127 in the world, with a per capita income of only $1.4 \mathrm{mu}$. China's land reserve resources are also very small. Due to social and economic development, the need to accelerate urbanization and restore ecosystems, there is no way to change the reduction of cultivated land. The food of more than 1.3 billion people is still an important issue. Therefore, how to rationally use existing land and improve the utilization efficiency of existing agricultural land resources is a major and urgent issue.

The possibility of the formation of rural land transfer market mechanism: farmland is a resource with commodity attributes. As agricultural products become more and more commodities, agricultural land, as an irreplaceable production factor, also exhibits commodity attributes and participates in circulation and exchange. The successful implementation of the urban land market allocation and the many years of exploration of the marketization of agricultural land in many parts of the country provide a practical basis for the establishment of the land transfer market mechanism. In the southeastern coastal areas, with the development of the economy, the market mechanism has shown an upward trend in the land transfer price (Table 1). At the same time, the transfer of rural labor has made some farmers have the desire to give up land use rights, and the gradual establishment of rural social security system will also relieve the worries of these farmers, which provides an objective basis for market-oriented allocation.

The reality of the formation of market mechanism: Market economy is the embodiment and foundation of commodity trading. Through market economy regulation of land circulation, it can influence land circulation in terms of supply and demand, competition and price, and regulate the distribution of resources and personal compensation. The market economic system has greatly improved farmers' commodity awareness in rural areas, and has stimulated farmers' sense of competition and labor enthusiasm, which are changing the behavior and thinking of farmers. The establishment of a market economic system has gradually increased the interaction between closed and backward rural areas and cities, Transfer more rural population to the city (Fig. 5), and has raised the level of development of the rural economy [4].

How to construct China's agricultural land transfer market mechanism. The implementation of the rural land transfer system is to maximize the benefits of the land and maximize the interests of the peasants. In the process of circulation, the following basic principles should be adhered to: First, the land use must not be changed. The use of cultivated land cannot be changed, and the cultivated land cannot be converted into noncultivated land in the name of circulation. It is 


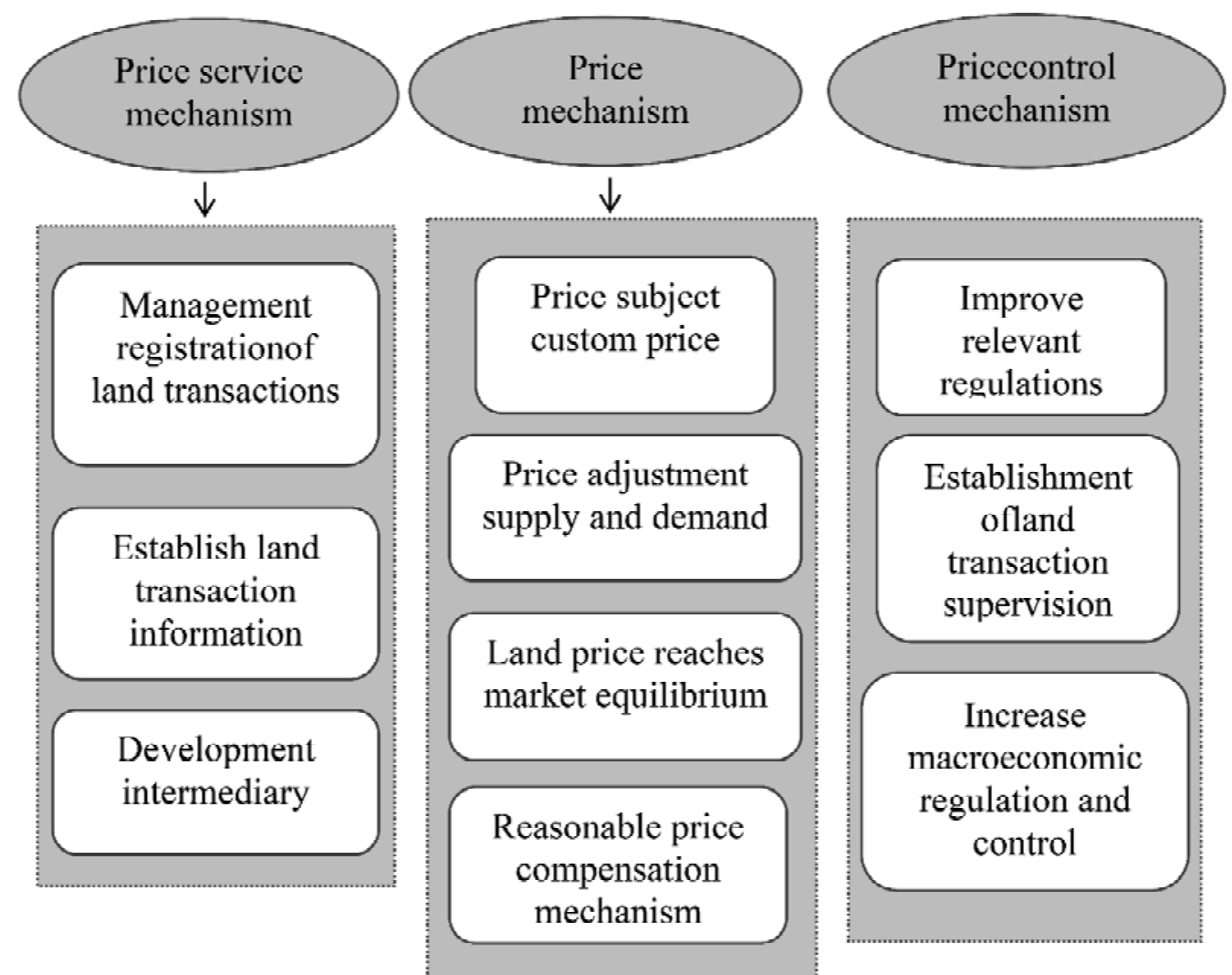

Fig. 6. Land transfer supply and demand price mechanism

necessary to protect cultivated land and ensure food security. Second, the collective nature of the land must not be changed. The purpose of rural land transfer is to optimize the allocation of land resources, improve the efficiency of land production, maximize the economic and social benefits of land, and never change the collective ownership of rural land. Third, the farmer's land contractual rights and interests must not be harmed. Farmers' land contracting rights are an important right of farmers. They include farmers' right to use land, management rights and income rights. They have economic functions and social security functions. For farmers, land is everything, and must not be in the process of land transfer. Damage to farmers' rights and interests. Fourth, the market mechanism is combined with macroeconomic regulation. The continuous establishment and improvement of the market economic system will inevitably require the market to play a fundamental role in resource allocation. However, the market mechanism itself has its own shortcomings, often giving priority to interests and ignoring social benefits [5]. The state must ensure that market entities pursue maximum benefits while not damaging social benefits, achieving current interests and long-term interests, and unifying the local interests and overall interests. Therefore, market mechanisms and macro-control must be implemented in the process of rural land transfer. The combination of land transfer makes China's economic development compatible with China's economic development.

The market operation mechanism generally includes the price mechanism, supply and demand mechanism, and competition mechanism. This is also the three major elements of China's rural land transfer market mechanism.

Farmland circulation price formation mechanism (Fig. 6). In market economy transactions, the role of price in resource allocation is very important. The land transfer price is the core of the land transfer market. It can reflect the rural land transfer status and reveal the supply and demand relationship of the transfer land. The land transfer price is determined through the land transfer market. The price is a signal for adjusting the scale of the transaction and the trading time for the land transfer right. For the purchaser, it is the basis for adjusting the demand content and demand. The marketization of land transfer will inevitably require the price mechanism to play an important role in it. Through the adjustment of land circulation price, the balance of supply and demand in the land transfer market will be realized, and the allocation of rural land resources will be optimized [6]. The information disclosure platform for improving land transfer prices makes land price information easy to obtain and highly transparent. 


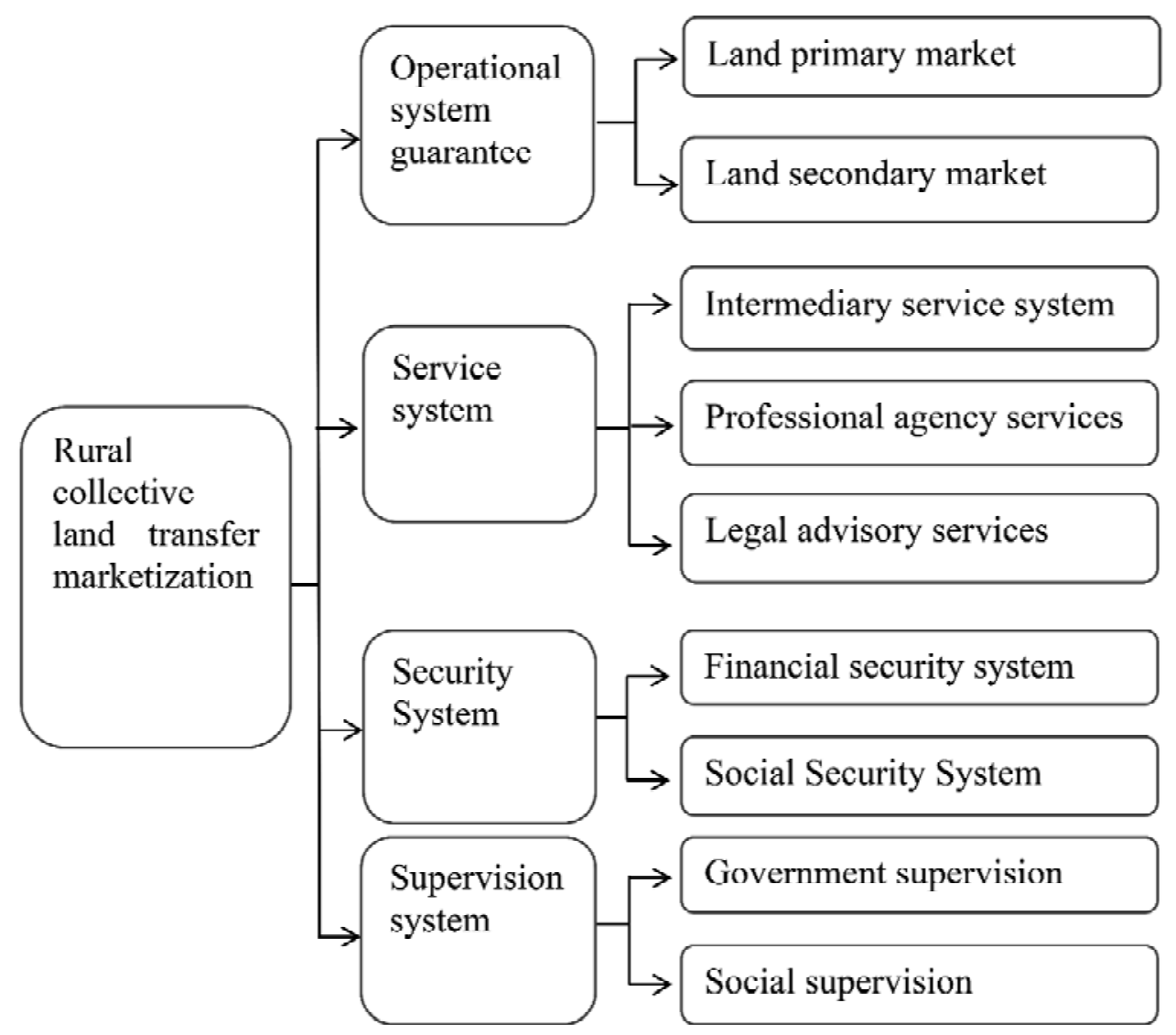

Fig. 7. Rural soil flow marketization system structure diagram

At the same time, we must also vigorously develop rural land transfer intermediaries.

Supply and demand mechanism: The land transfer market supply and demand mechanism is the combination point of the transfer land. The best state of supply and demand operation is to let the supply and demand sides achieve their goals. At present, the demand for land circulation is increasing. The purpose of demand is diversity development. Some farmers use it themselves, and some develop scale operations, which are often affected by the economic situation. The relationship between supply and demand often reflects the inherent relationship between price and supply and demand. If the supply of land is less than demand, it is very likely that the price will rise [7]. Of course, it will stimulate the flow of land supply. If there is more land supply, less demand, and the price of circulation is lower. Inevitably, at this time, the demand for land transfer will increase. Therefore, it is very important to establish a reasonable flow of land supply and demand mechanism.

Competition mechanism: Land transfer market competition occurs between buyers and sellers. Land is a non-renewable resource with limited supply. Therefore, competition is more intense than other markets. It is better to establish and improve market competition mechanism, maintain fair and reasonable competition in the market, and ensure the equal status of market entities. Competition will inevitably lead to the survival of the fittest. In the process of competition, the competitors must abide by the law and law, and the functional departments should abide by the law and achieve orderly competition. Don't waste or use insufficient land resources in rural areas because of excessive competition. Of course, they cannot unite to monopolize the market.

Innovation of land transfer carriers and implementation of a new type of land joint-stock cooperative system. Establish a land assessment team to evaluate the transferred land, then convert it into shares and distribute the shares to farmers. Establish land joint-stock cooperatives and elect leading bodies through the General Assembly, which perform land ownership and use rights and management. The system of land joint-stock cooperation enables farmers to acquire property rights and management rights in a real sense, thus participating in market operation. Establishing and improving the agricultural land market system, the rural land transfer market should set up market system including agricultural land ownership, use rights and rural financial market according to local 
conditions. The main task of this market is to establish modern agricultural services and speed up land transfer [8].

Due to the market itself has its drawbacks, we must join the national macro-control. Agriculture is not only a matter of food and economy, but also a matter of politics. In the process of rural land transfer, we should always pay attention to this problem, which determines that the rural land transfer behavior should be macro-controlled, make up for the defects of market mechanism in the transfer of land contractual management rights, build a harmonious society, and achieve sound and rapid development. Improve the rural land transfer marketization system in China through the above methods (Fig. 7).

\section{CONCLUSIONS AND PERSPECTIVES OF FURTHER RESEARCH}

The innovation of this paper is to analyze the agricultural land transfer in China from the perspective of market mechanism, put forward corresponding theories from the aspects of feasibility, reality and necessity, and find out the corresponding according to the current situation of land circulation in China. Its solution.

Through analysis and arrangement, the main conclusions and suggestions of this paper are as follows: First, the degree of marketization of rural land transfer in China is low. To promote the smooth development of land transfer and marketization, it is necessary to improve the corresponding market mechanism and related supporting facilities. Let the role of the market mechanism be fully utilized to promote the rational flow of rural land to improve the efficiency of allocation. Second, the marketization of land circulation cannot rely solely on the market. The government's macroeconomic regulation and control should play a corresponding auxiliary role, but it cannot be too strong. The government should establish a sound rural social security system to solve worries for farmers. Third, there is competition in the market mechanism, and the winners are eliminated. Farmers, as a weak subject in the process of land transfer, should receive more education, training and benefit protection, in order to better establish themselves in the market mechanism of land transfer.

References:

1. Guo Dong, (2018), Study on the Current Rural Land Transfer Model in China, Economic science press, Beijing, China.

2. Fan Ming, (2018), Land transfer and moderate scale operation, social sciences academic press, Beijing, China.
3. Chen Yinrong and Mei Yun, (2017), Research on Rural Land Transfer Transaction Mechanism and System, Science Press, Beijing, China.

4. Lv Shichen, (2012), Farmers' Social Security under the Rural Land Transfer System, social sciences academic press, Beijing, China.

5. Ding Donghong and Peng Buzhuo, (2010), "Three essential characteristics of modern land property rights system", Issues in Agricultural Economy, No. 5, PP. 28-30.

6. Deng Dacai, (2000), "Barriers to the flow of rural land use rights", Journal of Yangzhou University, No. 4, PP. 43-48.

7. Zhang Hongyu, (2008), "China's rural land property rights policy: continuous innovation", Chinese Rural Economy, No. 9, PP. 8-18.

8. Zheng Jingji and Xu Yiding, (2014), "Research on Commercialization of Rural Land Use Right in China", The Economist, No. 6, PP. 35-39.

Стаття надійшла до редакиї 20.05.2019 p.

Науково-практичний журнал «ЕКОНОМІКА ТА ДЕРЖАВА»

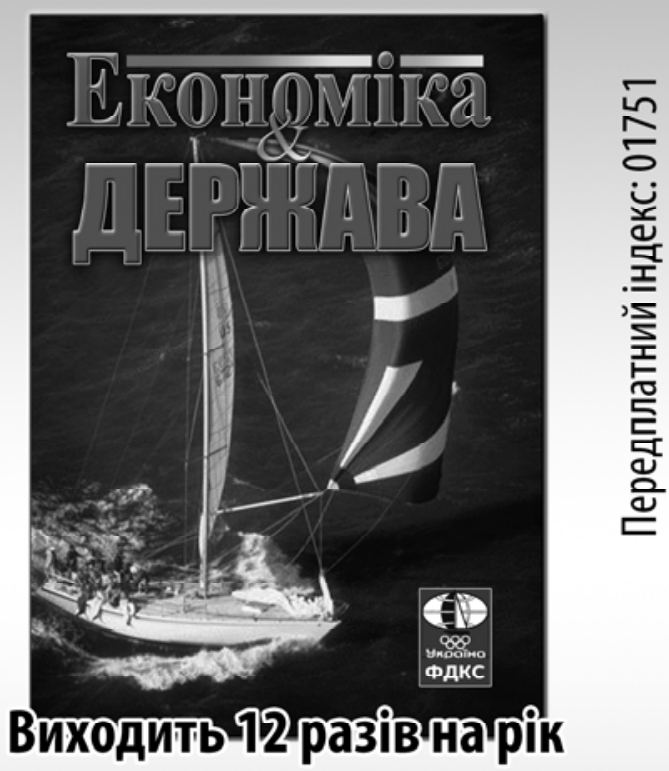

Журнал включено до переліку наукових фахових видань України з ЕКОНОМІКИ

www. economy.in.ua

e-mail:economy_2008@ukr.net тел.: (044) 223-26-28 (044) $458-10-73$ 